\title{
KAJIAN PEMANFAATAN SLUDGE IPAL KOTA JOGJAKARTA SEBAGAI PUPUK ORGANIK YANG RAMAH LINGKUNGAN
}

\author{
M. Yazid, Mintargo K, E. Supriyatni, ME. Budiono \\ Puslitbang Teknologi Maju - BATAN
}

\begin{abstract}
ABSTRAK
KAJIAN PEMANFAATAN SLUDGE IPAL KOTA JOGJAKARTA SEBAGAI PUPUK ORGANIK YANG RAMAH

LINGKUNGAN. Telah dilakukan pengkajian kemungkinan pemanfaatan sludge IPAL kota Yogyakarta sebagai pupuk organik ditinjau dari berbagai aspek antara lain kandungan unsur nutrien tanaman, logam berat dan dilakukan upaya untuk mematikan mikroba patogennya. Hasil pengkajian ini diharapkan dapat digunakan sebagai bahan pertimbangan untuk menganalisis dampak penggunaan sludge tersebut sebagai pupuk. Sampel sludge diambil dari Instalasi Pengolahan Air Limbah Kota Jogjakarta yang berlokasi di Bantul. Sampel sludge dikeringkan pada suhu kamar, dihaluskan dan ditimbang sesuai keperluan jenis analisisnya. Untuk analisis unsur makro dilakukan dengan metode Analisis Pengaktifan Netron Cepat (APNC), sedangkan unsur mikro menggunakan Analisa Pengaktifan Netron (APN). Pencacahan cuplikan menggunakan spektrometer gamma dengan detektor $\mathrm{Ge}(\mathrm{Li})$. Analisis logam berat $\mathrm{Pb}, \mathrm{Cd}$ dan $\mathrm{Hg}$ dilakukan menggunakan AAS, sedangkan $\mathrm{Sm}, \mathrm{Th}, \mathrm{Sb}, \mathrm{Cr}$ dan Co menggunakan APN. Sedangkan upaya untuk mematikan mikroba patogen dilakukan dengan irradiasi sampel menggunakan irradiator Co-60 dengan variasi dosis 5, 10, 15, 20 dan 25 kGy. Pengamatan mikrobiologis dilakukan di Laboratorium Mikrobiologi, Fakultas Biologi UGM yang meliputi , bakteria total, Escheria coli, Streptococcus dan Salmonella. Dari hasil analisis dapat diketahui bahwa kandungan unsur hara makro rerata yaitu $N$ sebesar 4,10 $\pm 0,007$ ppm, $P$ sebesar 640,51 $\pm 14,34 \mathrm{ppm}$ dan $\mathrm{K}$ sebesar 3,04 $\pm 0,06 \mathrm{ppm}$, sedangkan unsur mikro yang meliputi unsur $\mathrm{Mg}=$ $79,31 \pm 6,48 \mathrm{ppm}, \mathrm{Zn}=599,8 \pm 42,2 \mathrm{ppm}, \mathrm{Cu}=16,13 \pm 0,4 \mathrm{ppm}, \mathrm{Ca}=117,6 \pm 9,20 \mathrm{ppm}$ dan $\mathrm{Fe}=4,35 \pm 0,18 \%$. Sedangkan kisaran kandungan logam berat yang meliputi $P b=73,27-125,65 \mathrm{ppm}, \mathrm{Cd}=1,44-2,59 \mathrm{ppm}$, $\mathrm{Hg}$ tidak terdeteksi. Selain itu, $\mathrm{Sm}=0,04-18,68 \mathrm{ppm}, \mathrm{Th}=2,20-6,37 \mathrm{ppm} ; \mathrm{Sb}=1,06-76,37 \mathrm{ppm}, \mathrm{Cr}=1,94-51,40 \mathrm{ppm}$ dan Co $=0,57-84,03$ ppm. Adapun populasi bakteri yang terbesar adalah Salmonella sp, kemudian Streptococcus dan yang terakhir Escheria coli. Dari hasil analisis tersebut dapat disimpulkan bahwa sludge IPAL kota Yogyakarta dapat dimanfaatkan sebagai pupuk organik dengan perlakuan khusus agar unsur $\mathrm{Cu}$, $\mathrm{Fe}$ dan $\mathrm{Zn}$ tidak melebihi nilai kritis sehingga menghambat pertumbuhan tanaman, sedangkan kandungan berbagai logam berat masih dinilai cukup aman. Adapun dosis efektif untuk menekan populasi bateri total adalah $25 \mathrm{kGy}$, sedangkan untuk Salmonella sp sebesar $20 \mathrm{kGy}$ dan Escheria coli adalah $15 \mathrm{kGy}$. Kandungan logam berat di dalam sludge yang tertinggi adalah timbal $(\mathrm{Pb})$ yaitu sebesar 125,65 ppm
\end{abstract}

\section{ABSTRACT}

STUDY ON THE USE OF SLUDGE FROM JOGJAKARTA WASTE WATER PROCESSING PLANT AS ENVIRONMENTAL FRIENDLY ORGANIC FERTILIZER. Study on feasibility of the use of sludge from Jogjakarta Waste Water Processing Plant (JWWPP) as organic fertilizer with several aspects to be considered, such as plant nutrient content, heavy metal content and its pathogenic microbial. From the observation result is expected can be used as an input data for analyzing the use of sludge impact as fertilizer. Sludge sample was taken from JWWPP that located at Bantul. Sludge sample was dried at the room temperature, grinded and weighed to be appropriate to the analysis type. The macro element content was analyzed using Neutron Activation Analysis (NAA), then counted using $\mathrm{Ge}(\mathrm{Li}) \mathrm{Gamma}$ Spectrometer. The heavy metal content, such as $\mathrm{Pb}, \mathrm{Cd}$ and $\mathrm{Hg}$ was analyzed using AAS, while for $\mathrm{Sm}, \mathrm{Th}, \mathrm{Sb}, \mathrm{Cr}$ and $\mathrm{Co}$ contents were analyzed using NAA. Sample was irradiated in order to kill pathogenic microbial, using varied doses which are 5, 10, 15, 20 and $25 \mathrm{kGy}$. Microbial observation was carried out at Microbiological Laboratory of Biological Faculty-Gadjah Mada University that include of total bacteria, Escheria coli, Streptococcus and Salmonella. The average macro element content was determined from the analysis result, $N$ is $4.10 \pm 0.007 \mathrm{ppm}, P$ is $640.51 \pm 14.34, K$ is $3.04 \pm 0.06 \mathrm{ppm}$, while micro element content consist of Mg is $79.31 \pm$ $6.48 \mathrm{ppm}, \mathrm{Zn}$ is $599.8 \pm 42.2 \mathrm{ppm}, \mathrm{Cu}$ is $16.13 \pm 0.4 \mathrm{ppm}, \mathrm{Ca}$ is $117.6 \pm 9.20 \mathrm{ppm}$ and $\mathrm{Fe}$ is $4.35 \pm 0.18 \mathrm{ppm}$. The range of heavy metal content consist of $\mathrm{Pb}$ is $73.27-125.65 \mathrm{ppm}, \mathrm{Cd}$ is $1.44-2.59 \mathrm{ppm}$, while $\mathrm{Hg}$ is undetected. Another that $\mathrm{Sm}$ is $0.04-18.68 \mathrm{ppm}$, Th is $2.20-6.37 \mathrm{ppm}$; Sb is $1.06-76.37 \mathrm{ppm}, \mathrm{Cr}$ is $1.94-51.40 \mathrm{ppm}$ and Co is $0.57-84.03 \mathrm{ppm}$. The greatest bacteria population is Salmonella sp, then Streptococcus and the latest is Escheria coli. The analysis result can be deduced that sludge from JWWPP can be used as organic fertilizer with 
Kajian pemanfaatan sludge ipal kota Jogjakarta sebagai pupuk organik yang ramah lingkungan

specific treatment to decrease $\mathrm{Cu}, \mathrm{Fe}$ and $\mathrm{Zn}$ content to be less then the critical value to hinder the growth of a plant. While the heavy metal content is still below safe value. Effective dose to suppress total bacteria population is $25 \mathrm{kGy}$, while for Salmonella sp is $20 \mathrm{kGy}$, Escheria coli is $15 \mathrm{kGy}$. The highest heavy metal content in the sludge is lead (Pb) which is $125,65 \mathrm{ppm}$.

\section{PENDAHULUAN}

$\mathrm{D}$ engan semakin berkembangnya wilayah industri maupun pemukiman di suatu perkotaan, maka lazimnya akan diikuti dengan permasalahan air limbah yang berasal dari kegiatan tersebut. Berbagai jenis instalasi pengolahan air limbah (IPAL) telah dibangun dan dioperasikan yang mampu menjernihkan kembali air limbah sesuai baku mutu lingkungan. Di samping itu, juga diperoleh endapan lumpur (sludge) yang merupakan konsentrat dari berbagai pencemar terkandung di dalam air limbah yang diolah, sehingga dikhawatirkan akan menimbulkan permasalahan baru bagi kehidupan manusia. Dengan semakin bertumpuknya sludge dikhawatirkan akan membahayakan kesehatan masyarakat dan lingkungan, karena menurut HASHIMOTO, S (1995) di dalam sludge tersebut pada umumnya terkandung jasad renik patogen baik berupa virus, bakteria, protozoa ataupun telur parasit ${ }^{(1)}$ Beberapa metode ditawarkan untuk penyelesaian permasalahan tersebut, diantaranya penggunaan radiasi pengion untuk desinfeksi jasad renik patogen tersebut.

Selain itu, karena air limbah perkotaan yang diolah di IPAL tersebut berasal dari berbagai kegiatan antara lain rumah tangga, pasar dan industri kecil maka ada kemungkinan mengandung logam berat yang membahayakan lingkungan. Logam berat tersebut kemungkinan besar akan turut terendapkan di dalam sludge hasil pengolahan limbah itu. Sebenarnya pada umumnya di dalam sludge masih terkandung nutrisi tanaman yang berasal dari dekomposisi senyawa organik yang terkandung di dalamnya, sehingga kemungkinan masih memiliki nilai komersial yang tinggi di bidang agronomi.

Nutrisi tanaman terdiri dari unsur hara makro yang sangat diperlukan dalam jumlah yang banyak untuk pertumbuhan tanaman, yang meliputi $\mathrm{N}, \mathrm{P}, \mathrm{K}$ yang biasanya diperoleh dari pupuk dan $\mathrm{C}, \mathrm{H}, \mathrm{O}$ yang didapatkan dari udara dan air. Sedangkan jenis unsur hara mikro yang diperlukan oleh tanaman dalam jumlah yang kecil saja, tetapi sangat esensial dalam periode tertentu ${ }^{(2)}$ Misalnya : proses pembungaan ataupun pembentukan buah. Jenis unsur ini antara lain $\mathrm{Fe}, \mathrm{Mn}, \mathrm{Cu}$, dan $\mathrm{Zn}$.

Unsur $\mathrm{N}, \mathrm{P}$ dan $\mathrm{K}$ merupakan unsur hara makro yang mutlak diperlukan oleh tanaman, misalnya unsur $\mathrm{N}$ sangat penting dalam pembentukan protein, merangsang pertumbuhan vegetatif dan meningkatkan hasil buah. Unsur dapat merangsang pembungaan, meningkatkan jumlah dan volume buah serta meningkatkan ketahanan terhadap gangguan hama dan penyakit tanaman. Unsur $\mathrm{K}$ berperan dalam sintesa karbohidrat dan protein sekaligus memperkokoh tanaman agar bunga dan buah tidak berguguran. ${ }^{(3)}$

Proses pengolahan limbah kota Yogyakarta diawali dari sambungan pipa rumah ke pipa lateral masuk ke pipa induk menuju ke lokasi IPAL dan disalurkan ke rumah pompa. Air limbah diangkat dengan pompa tipe ulir dan dialirkan ke bak pengendap pasir, di tempat ini pasir dan kerikil halus diendapkan.

\section{TATA KERJA}

\section{Bahan Yang Diperlukan}

Sludge dari IPAL Kota Jogjakarta yang berlokasi di Bantul, sampel standar yang digunakan dalam analisis Pengaktifan netron, sarung tangan plastik dan kantong plastik untuk perlengkapan sampling, baki plastik, vial polietilen untuk preparasi sample, nitrogen cair dan gas nitrogen yang diperlukan dalam pengoperasian spektrometer gamma.

\section{Peralatan Yang Digunakan}

Perahu yang diperlukan untuk sampling di tengah kolam, lumpang porselin, ayakan dan timbangan analitik yang diperlukan untuk preparasi sampel. Sedangkan aktivasi sampel dilakukan di dalam reaktor Kartini dan spektrometer gamma dengan detektor $\mathrm{Ge}(\mathrm{Li})$ digunakan untuk pencacahan dan identifikasi unsur di dalam sludge. 


\section{Cara Kerja}

\section{a. Pengambilan sampel sludge}

Sampel diambil dari Instalasi Pengolahan Air Limbah (IPAL) Perkotaan Jogjakarta yang berlokasi di Bantul. Adapun sampel yang diambil dibedakan menjadi dua yaitu :

1. Sludge kering diambil di bak penampungan.

2. Sludge segar yang diambil langsung dari dasar kolam aerasi fakultatif dan kolam pematangan menggunakan perahu.

\section{b. Preparasi Sampel}

1. Sampel sludge dikeringanginkan di atas baki plastik dan dibiarkan kering dalam suhu kamar.

2. Setelah kering, dihaluskan menggunakan lumpang porselin dan diayak dengan ukuran butir lolos 100 mesh.

3. Ditimbang masing-masing 0,5 gram cuplikan dan dimasukkan ke dalam vial polietilen dan ditutup rapat.

\section{c. Analisis Cuplikan}

1. Untuk analisis unsur hara makro $(\mathrm{N}, \mathrm{P}, \mathrm{K})$ dilakukan dengan analisis pengaktifan netron cepat yang pada prinsipnya iradiasi cuplikan dilakukan menggunakan generator netron

2. Sedangkan analisis unsur mikro ( $\mathrm{Mg}, \mathrm{Zn}, \mathrm{Cu}, \mathrm{Ca}$ dan $\mathrm{Fe}$ ), dilakukan dengan analisis pengaktifan netron yang irradiasi cuplikannya dilakukan di di dalam reaktor Kartini.

3. Untuk analisis kandungan logam berat $(\mathrm{Pb}, \mathrm{Cd}$ dan $\mathrm{Hg}$ ) dilakukan menggunakan spektrofotometer serapan atom (AAS), sedangkan untuk $\mathrm{Sm}, \mathrm{Th}, \mathrm{Sb}, \mathrm{Cr}$ dan $\mathrm{Co}$ dilakukan dengan analisis pengaktifan netron pula.

\section{HASIL DAN PEMBAHASAN}

Pada Gambar 1 disajikan perbandingan antara kandungan unsur makro di dalam sludge dan kebutuhan baku nutrisi tanaman secara optimal. Dari gambar tersebut diketahui bahwa kandungan unsur $\mathrm{P}$ di dalam sludge tersebut sangat tinggi jika dibandingkan dengan jumlah yang dibutuhkan oleh tanaman, bahkan sampai di atas $1400 \%$ dibandingkan dengan kebutuhan baku unsur tersebut. Seperti telah diketahui bersama bahwa unsur $P$ berperanan penting dalam merangsang pembungaan, meningkatkan jumlah dan volume buah dan meningkatkan ketahanan terhadap gangguan hama dan penyakit tanaman. ${ }^{(3)}$

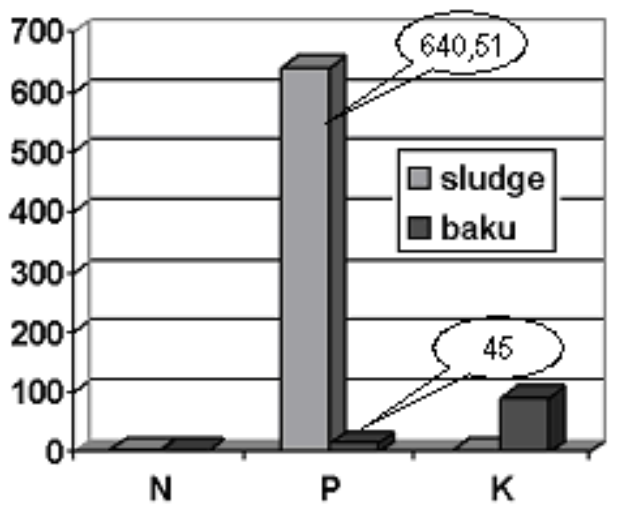

Gambar 1 Perbandingan kandungan unsur makro di dalam sludge dengan kebutuhan baku nutrisi tanaman

Namun, fungsi tersebut masih harus mendapatkan dukungan dari parameter-parameter pertumbuhan yang lain. Misalnya, proses rangsangan pembungaan itu tidak akan dapat terjadi jika pertumbuhan vegetatif tanaman itu tidak subur, artinya tanaman yang kecil dan kurus tidak akan mampu berbunga walaupun sudah dilakukan perangsangan, apalagi untuk berbuah yang lebat dan volumenya besar. Padahal peranan menyuburkan pertumbuhan vegetatif dan pembentukan buah dilakukan oleh unsur $\mathrm{N}$.

Ditinjau dari aspek kandungan unsur $\mathrm{N}$ di dalam sludge ternyata hampir $400 \%$ dibandingkan dengan kebutuhan baku unsur yang sama. Namun demikian, masih dalam kategori sangat tinggi. Seperti telah kita 
ketahui bersama, bahwa peranan unsur $\mathrm{N}$ di dalam pertumbuhan tanaman adalah dalam sintesa protein, merangsang pertumbuhan vegetatif dan meningkatkan jumlah dan volume buah. ${ }^{(3)}$

Salah satu alternatif untuk mengatasi kelebihan $\mathrm{N}$ digunakan N-Balancer yang mampu mengubah unsur nitrat menjadi $\mathrm{N}$ yang berguna untuk meningkatkan pertumbuhan generatif. Pertumbuhan vegetatif yang semula berlebihan lalu diturunkan. Selain itu, juga menjaga keseimbangan hormon yang kelebihan unsur nitrat, yang akhirnya kegiatan transportasi karbohidrat, metabolisme dan pertumbuhan bunga, buah, biji dan umbi menjadi lebih aktif.

Sedangkan kandungan unsur $\mathrm{K}$ di dalam sludge masuk dalam kategori sangat rendah jika dibandingkan dengan nilai baku yang dibutuhkan oleh tanaman. Unsur $\mathrm{K}$ berperan dalam sintesa karbohidrat dan protein sekaligus memperkokoh tanaman agar bunga dan buah tidak berguguran. Memang demikianlah salah satu kelemahan pupuk organik dimana komposisi NPK biasanya tidak seimbang seperti pada pupuk buatan. Namun demikian, pupuk organik dapat berfungsi untuk memperbaiki sifat tanah selain juga sebagai sumber unsur mikro. Kehadiran unsur mikro ini, akan menyeimbangkan nutrisi yang diterima oleh tanaman, yang di dalam siklus hidupnya membutuhkan unsur tersebut.

Kandungan unsur di dalam sludge segar maupun kering ternyata untuk unsur Mg masuk dalam kriteria rendah sampai sedang. Adapun untuk unsur $\mathrm{Ca}$ untuk kedua jenis sludge masuk dalam kriteria sangat rendah. Sedangkan untuk unsur $\mathrm{Cu}$, Fe dan $\mathrm{Zn}$ di dalam sludge baik untuk sludge segar maupun kering, ternyata semuanya melebihi nilai kritis, maka jika akan digunakan sebagai pupuk organik masih memerlukan perlakuan khusus untuk menurunkan kandungan ketiga unsur tersebut agar di bawah nilai kritisnya. Penurunan kandungan unsur tersebut tidak dapat dilakukan dengan cara pengenceran menggunakan teknik pencampuran dengan tanah lempung atau pasir, namun hal ini juga akan menurunkan kandungan unsur $\mathrm{Ca}$ dan $\mathrm{Mg}$ yang kandungannya di dalam sludge sudah sangat rendah.

Hal ini diperkuat dengan hasil penelitian yang dilakukan oleh MURTIKA, D, (1999) bahwa pemanfaatan sludge untuk penanaman jagung manis (Zea mays. L cv. Sachanata Sturt) menunjukkan hasil baik apabila digunakan komposisi sludge di bawah $50 \%$, sedangkan jika digunakan sludge di atas $50 \%$ justru akan menghambat pertumbuhan tanaman tersebut. ${ }^{(4)}$ Penghambatan pertumbuhan tanaman tersebut diduga karena kandungan unsur $\mathrm{Fe}, \mathrm{Zn}$ dan $\mathrm{Cu}$ tersebut yang melampaui nilai kritisnya sehingga akan bersifat racun terhadap pertumbuhan tanaman jagung tersebut.

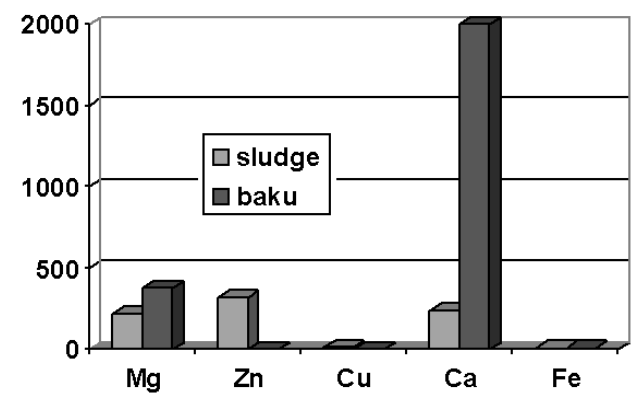

Gambar 2 Perbandingan antara kandungan unsur mikro di dalam sludge dengan kebutuhan nutrisi tanaman

Data populasi bakteria indikator setelah dilakukan irradiasi gamma dengan variasi dosis 0 (tanpa irradiasi), 5, 10, 15 dan $20 \mathrm{kGy}$ disajikan pada Tabel 1. Dari data tersebut dapat diketahui bahwa sebelum dilakukan irradiasi Salmonella $s p$ memiliki populasi terbesar dibandingkan dengan kedua jenis bakteria lainnya. Secara umum ketiga jenis bakteri tersebut terdapat di dalam limbah domestik, karena habita sebenarnya adalah di dalam tubuh manusia dan hewan di dalam intestinum, sehingga akan ikut terkeluarkan dari tubuh bersama dengan feses. Hal ini sesuai dengan hasil penelitian yang dilakukan HASHIMOTO, S (1995) yang menyatakan bahwa bakteri patogen yang terdapat di dalam sludge $90 \%$ adalah Salmonella sp dan sebagian lagi jenis lainnya. Selain kandungan zat organik, lemak dan garam-garam terlarut yang terkandung di dalam sludge mendukung tumbuh suburnya Salmonella $s p .^{(1)}$ 
Tabel 1. Populasi Bakteria Indikator Setelah Dilakukan Irradiasi Gamma

\begin{tabular}{|c|c|c|c|}
\hline \multirow{2}{*}{$\begin{array}{c}\text { Dosis irradiasi } \\
\text { kGy }\end{array}$} & \multicolumn{3}{|c|}{ Populasi bakteri per gram sludge } \\
\cline { 2 - 4 } & Escheria coli & Streptococcus sp & Salmonella sp \\
\hline 0 & 50 & $7,4 \times 10^{3}$ & $1,2 \times 10^{4}$ \\
\hline 5 & - & $8,0 \times 10^{3}$ & $8,9 \times 10^{2}$ \\
\hline 10 & - & $3,4 \times 10^{3}$ & $8,3 \times 10^{1}$ \\
\hline 15 & 10 & $5,9 \times 10^{3}$ & - \\
\hline 20 & 30 & $3,9 \times 10^{3}$ & - \\
\hline
\end{tabular}

Jika dibandingkan dengan dosis irradiasi 0 (tanpa irradiasi), dengan peningkatan dosis irradiasi gamma terlihat bahwa populasi dari ketiga jenis mikroba tersebut cenderung menurun sejalan dengan meningkatnya dosis irradiasi. Hal ini disebabkan radiasi akan menyebabkan penghambatan proses sintesis DNA pada dosis rendah dan perubahan susunan DNA yang akhirnya menyebabkan kekacauan dalam proses sintesis protein. Sedangkan pada dosis irradiasi yang tinggi menyebabkan DNA template akan rusak sehingga sintesis DNA terhambat yang akhirnya sel bakteri akan rusak dan mati. Selain itu, perlu diingat bahwa protein dalam sel merupakan komponen dasar pembentukan enzim dan asam nukleat, akibatnya proses metabolisme dalam sel terganggu dan pertumbuhan akan terhambat ${ }^{(5)}$

Kandungan logam berat yang meliputi $\mathrm{Pb}, \mathrm{Cd}$ dan $\mathrm{Hg}$ serta $\mathrm{Sm}, \mathrm{Th}, \mathrm{Sb}, \mathrm{Cr}$ dan $\mathrm{Co}$ di dalam sludge di dalam kolam penampungan disajikan pada Tabel 2 Kandungan logam berat di dalam sludge tersebut kemungkinan berasal dari limbah rumah tangga/domestik, pertokoan, pasar serta industri kerajinan yang berada di kawasan kota Jogjakarta yang kadarnya masih bersifat alami sehingga belum sampai tingkat yang membahayakan kehidupan. Untuk itu, tidak diperlukan instalasi khusus untuk memisahkan logam tersebut di dalam IPAL Kota Jogjakarta.

Jika dilihat hasil analisis logam berat di dalam Tabel 2 dapat diketahui bahwa kandungan yang terbesar adalah $\mathrm{Pb}$ (timbal) yaitu sebesar 125,65 ppm. Kemungkinan unsur ini berasal dari timbal yang sudah terkandung di dalam air, makanan, dan udara. $\mathrm{Pb}$ di atmosfer berasal dari senyawa hasil pembakaran bensin reguler dan premium yang tidak sempurna. Biasanya kadar $\mathrm{Pb}$ dalam tanah berkisar $5-25 \mathrm{ppm}$, dalam air tanah $1-60 \mathrm{ppm}$ dan agak lebih rendah dalam air permukaan. Air minum dapat tercemar cukup tinggi oleh $\mathrm{Pb}$ karena penggunaan pipa berlapis $\mathrm{Pb}$, peralatan makanan keramik berglasur merupakan sumber $\mathrm{Pb}$ yang lain. ${ }^{(5)}$

Tabel 2. Hasil analisis logam berat secara kuantitatif di dalam sludge

\begin{tabular}{|l|l|c|}
\hline No. & Nama Unsur & Kadar $(\mathrm{Ppm})$ \\
\hline 1. & Plumbum $(\mathrm{Pb})$ & 125,65 \\
\hline 2. & Kadmium $(\mathrm{Cd})$ & 2,16 \\
\hline 3. & Merkuri $(\mathrm{Hg})$ & tidak terdeteksi \\
\hline 4. & Samarium $(\mathrm{Sm})$ & 18,68 \\
\hline 5. & Thorium $(\mathrm{Th})$ & 0,58 \\
\hline 6. & Sorbidium $(\mathrm{Sb})$ & 4,58 \\
\hline 7. & Kromium $(\mathrm{Cr})$ & 1,73 \\
\hline 8. & Kobalt $(\mathrm{Co})$ & 0,56 \\
\hline
\end{tabular}

Timbal $(\mathrm{Pb})$ termasuk logam berat yang banyak dipergunakan dalam industri maupun pertanian. Apabila limbah industri dan pertanian dibuang langsung ke perairan tanpa melalui pengolahan terlebih dahulu, maka dapat menyebabkan pencemaran dan mengganggu keseimbangan lingkungan terutama pada biota perairan yang akhirnya akan membahayakan konsumen yang mengkonsumsi biota tersebut. Konsumen yang mengkonsumsi biota yang tercemar tersebut, secara lambat namun pasti akan membahayakan kesehatannya; mengingat logam $\mathrm{Pb}$ bersifat akumulatif artinya mudah tersimpan di dalam jaringan biologis. Untuk meminimalkan kadar $\mathrm{Pb}$ pada limbah industri dapat digunakan arang aktif. Tingkat pencemaran pada konsumen dapat dilakukan dengan analisis beberapa jaringan antara lain rambut para nelayan. ${ }^{(6)}$ 


\section{KESIMPULAN}

1. Kandungan unsur hara makro di dalam sludge untuk $P$ sangat tinggi, bahkan sampai di atas $4000 \%$ dibandingkan dengan kebutuhan baku. unsur $\mathrm{N}$ hampir $400 \%$ dibandingkan dengan kebutuhan baku unsur yang sama, sedangkan untuk unsur $\mathrm{K}$ masuk dalam kategori sangat rendah jika dibandingkan dengan nilai baku yang dibutuhkan oleh tanaman.

2. Ditinjau dari aspek kebutuhan nutrisi tanaman, kandungan unsur Mg masuk dalam kategori rendah - sedang, unsur $\mathrm{Ca}$ sangat rendah. Sedangkan untuk $\mathrm{Cu}$, $\mathrm{Fe}$ dan $\mathrm{Zn}$ melebihi nilai kritis.

3. Dosis efektif untuk menekan populasi Escheria coli adalah $15 \mathrm{kGy}$, sedangkan untuk Streptococcus dan Salmonella sp sebesar $20 \mathrm{kGy}$.

4. Kandungan logam berat di dalam sludge yang tertinggi adalah timbal $(\mathrm{Pb})$ yaitu sebesar $125,65 \mathrm{ppm}$

\section{DAFTAR PUSTAKA}

1. HASHIMOTO, S., Research and Development on Sludge Treatment, JAERI (1995)

2. PIADANG, S \& N. SUDHAPREDA., Evaluation of Component in Sludge, JAERI Research (1995)

3. SOMMERS, L.E., Chemical Composition of Sewage Sludge and Analysis of Their Potential Use as Fertilizers, USA (1977)

4. MURTIKA, D, Pemanfaatan Lumpur Hasil IPAL Yogyakarta Untuk Penanaman Jagung Manis (Zea mays. $L$ cV. Sachanata Sturt), Fakultas Biologi Universitas Gadjah Mada, Yogyakarta (1999)

5. CAHYADI. W., Bahaya Pencemaran Timbal pada Makanan dan Minuman, Departemen Farmasi, Pascasarjana ITB, Bandung (2004)

6. ZAINUL KAMAL., Penentuan Kadar Logam Logam Dan Radionuklida Dalam Ikan, Bintang Dan Gasing Serta Relevansinya Dengan Perencanaan Lingkungan , Belum dipulikasikan 